OPEN ACCESS

Edited by: Luc Pieters,

University of Antwerp, Belgium

Reviewed by:

Ipek Suntar.

Gazi University, Turkey

Stefan Gafner,

American Botanical Council,

United States

${ }^{*}$ Correspondence:

Namrita Lall

namrita.lal/@up.ac.za

Specialty section:

This article was submitted to

Ethnopharmacology,

a section of the journa

Frontiers in Pharmacology

Received: 10 November 2017

Accepted: 13 March 2018

Published: 10 April 2018

Citation:

Henley-Smith CJ, Botha FS,

Hussein AA, Nkomo M, Meyer D and Lall N (2018) Biological Activities of Heteropyxis natalensis Against Micro-Organisms Involved in Oral Infections. Front. Pharmacol. 9:291. doi: 10.3389/fphar.2018.00291

\section{Biological Activities of Heteropyxis natalensis Against Micro-Organisms Involved in Oral Infections}

\author{
Cynthia J. Henley-Smith ${ }^{1}$, Francien S. Botha ${ }^{2}$, Ahmed A. Hussein ${ }^{3}$, Mpumelelo Nkomo ${ }^{4}$, \\ Debra Meyer ${ }^{5}$ and Namrita Lall ${ }^{*}$
}

'Department of Plant and Soil Science, University of Pretoria, Pretoria, South Africa, ${ }^{2}$ Paraclinical Sciences, Faculty of Veterinary Sciences, University of Pretoria, Pretoria, South Africa, ${ }^{3}$ Chemistry Department, Cape Peninsula University of Technology, Bellville Campus, Cape Town, South Africa, ${ }^{4}$ Von Seidels Intellectual Property Attorneys, Cape Town,

South Africa, ${ }^{5}$ Faculty of Science, University of Johannesburg, Johannesburg, South Africa

The use of complementary and alternative medicine from plants in South Africa, as in the rest of the world, continues to increase. Heteropyxis natalensis, known as the Lavender tree, is indigenous to South Africa and is traditionally used for oral care. The ethanolic extract, of the leaves and twigs, of $H$. natalensis was investigated for antimicrobial activity against selected oral microorganisms. Actinomyces israelii was found to be the most sensitive oral microorganism to the extract, with a minimum inhibitory concentration (MIC) of $0.88 \mathrm{mg} / \mathrm{ml}$ and an $\mathrm{MIC}$ of $2.6 \mathrm{mg} / \mathrm{ml}$ against Streptococcus mutans. Five known compounds were identified from the ethanolic extract of $H$. natalensis. The compounds were identified as aurentiacin A (1), cardamomin (2), 5-hydroxy-7-methoxy-6-methylflavanone (3), quercetin (4) and 3,5,7-trihydroxyflavan (5). The MICs of the compounds 1 and 4 were found to be $0.06 \mathrm{mg} / \mathrm{ml}$ and $1 \mathrm{mg} / \mathrm{ml}$, respectively, against $A$. israelii. The cytotoxicity, acute and sub-acute toxicity in pre-clinical studies were also determined for $\mathrm{H}$. natalensis. The extract showed moderate cytotoxicity (35.56 $\pm 0.16 \mu \mathrm{g} / \mathrm{ml})$ on human monocyte cells. The acute and sub-acute toxicity analysis of $H$. natalensis indicated the NOEL (noobserved-effect level) at $200 \mathrm{mg} / \mathrm{kg}$. Interleukin-8 (IL-8) is a chemokine that stimulates the recruitment of leukocytes. A significant reduction of IL-8 production by macrophage cells was observed when exposed to the extract of $H$. natalensis. It is possible that $H$. natalensis can prevent excessive tissue damage in periodontal diseases through its reduction of inflammation. Enzymatic bioanalysis of lactic and acetic acid production from Streptococcus mutans and Lactobacillus paracasei was done. A reduction in the acid production from each bacterium was observed on exposure to the extract of $H$. natalensis. Consequently, this increased the $\mathrm{pH}$, which could possibly reduce the demineralization of enamel which may help prevent the formation of dental caries. In addition the extract may be considered for preventing periodontal diseases.

Keywords: Heteropyxis natalensis, Actinomyces israelii, antibacterial, compound isolation, anti-inflammatory 


\section{INTRODUCTION}

Heteropyxis natalensis Harv., belonging to the family Heteropyxidaceae, is commonly known as the Lavender Tree. It is distributed in the Limpopo, Gauteng, and KwaZuluNatal provinces of South Africa (Van Wyk and Van Wyk, 1997). It was listed by Van Wyk (2011), as an "indigenous South African plant species of historic, current or potential importance in the formulation of commercial medicine." Decoctions of the leaves and twigs of $H$. natalensis are traditionally used by Venda and Zulu communities as an oral rinse for toothache and for oral and gum infections (Van Wyk and Gericke, 2000).

Several mouth rinses have been developed as agents for the prevention of dental caries, but dental caries is still a major factor in tooth loss, worldwide. Therefore, development of new preventive agents for dental caries is needed (Yu et al., 2007). Natural products, either pure compounds or standardized plant extracts, provide unlimited opportunities for novel and suitable additives and drugs because of their unmatched range of chemical diversities (Klančnik et al., 2010).

This study investigated several biological activities of $H$. natalensis related to the human oral cavity. These investigations included: antimicrobial activity of $H$. natalensis against four pathogenic oral microorganisms, Actinomyces israelii, Streptococcus mutans, Prevotella intermedia, Candida albicans, and against Lactobacillus paracasei, a commensal bacterium essential in plaque prevention. Commensal bacteria should preferably not be affected by any treatment to help ensure a healthy immune system is maintained and to prevent opportunistic microorganisms taking a hold of the environment. When bacteria cause an infection, pro-inflammatory cytokines, such as interleukin-8 (IL-8), are released from cells and can cause tissue destruction, such as gum loss, through excessive inflammatory responses. Reduction of the release of proinflammatory cytokines may prevent excessive tissue damage in periodontal diseases, therefore the effect of extract on the release of cytokines was analyzed. Enzymatic bioanalysis of lactic and acetic acid production from the acid producing bacteria, S. mutans and L. paracasei was investigated on exposure to the plant extract. Isolation of compounds using bioassay guided fractionation for the identification of bioactive(s) from the plant was conducted. The extract's cytotoxicity, acute and sub-acute toxicity in mice were investigated to analyze the safety of the plant extract. This holistic approach covers the myriad of properties essential for an effective oral care pharmaceutical and/or alternative.

\section{MATERIALS AND METHODS}

\section{Plant Collection, Authentication, and Extract Preparation}

Aerial plant parts, comprising the leaves and twigs of $H$. natalensis were collected from the University of Pretoria's experimental farm. Voucher specimens were prepared and identified at the H.G.W.J. Schwelcherdt Herbarium (PRU), University of Pretoria (PRU 096405). Plant material was air dried at room temperature $\left(25^{\circ} \mathrm{C}\right)$, and ground to a homogeneous blend using a Janke and Kunkel (IKA Labortechnik, Germany) grinder. The homogeneous material was extracted with $96 \%$ ethanol [Merck Chemicals (Pty) Ltd., Wadeville, South Africa] under pressure (100 bar), and regulated temperature of $50^{\circ} \mathrm{C}$ using a BUCHI Speed Extractor, E-916 (BUCHI Labortechnik AG, Switzerland). The solvent was evaporated at low boiling point in a Genevac, EZ-2 plus, after which all the extracts were subjected to various biological tests.

\section{Antimicrobial Activity Microbial Strains}

The microorganisms used in this study included Actinomyces israelii (ATCC 10049), Prevotella intermedia (ATCC 25611), Streptococcus mutans (ATCC 25175), Lactobacillus paracasei (oral clinical strain A54), Candida albicans (ATCC 10231), and a strain of Candida albicans resistant to the drugs; imidazole and polyene (1051604). The bacteria were grown on Caseinpeptone Soymeal-peptone (CASO) Agar [Merck Chemicals (Pty) Ltd., Wadeville, South Africa] enriched with $1 \%$ sucrose [Merck Chemicals (Pty) Ltd., Wadeville, South Africa] under anaerobic conditions in an anaerobic jar with Anaerocult ${ }^{\circledR}$ A [Merck Chemicals (Pty) Ltd., Wadeville, South Africa], at $37^{\circ} \mathrm{C}$ for $48 \mathrm{~h}$. Candida albicans was grown on Sabouraud Dextrose 4\% Agar (SDA) [Merck Chemicals (Pty) Ltd., Wadeville, South Africa], at $37^{\circ} \mathrm{C}$ for $48 \mathrm{~h}$. Sub-culturing was done every second week. Inoculum was prepared by suspending microbial test organisms in enriched CASO broth [Merck Chemicals (Pty) Ltd.] for the bacteria and Sabouraud Dextrose 4\% broth [Merck Chemicals (Pty) Ltd.] for Candida until turbidity was found to be compatible with McFarland Standard 1 [Merck Chemicals (Pty) Ltd., Wadeville, South Africa] (McFarland, 1907).

\section{Determination of Minimum Inhibitory Concentration (MIC) and Minimum Bactericidal Concentration (MBC)}

The microdilution technique using 96-well micro-plates, as described by Eloff (1998) was used to obtain the MIC and $\mathrm{MBC}$ values of the crude extracts against the microorganisms under study. The extract was dissolved in 20\% dimethyl sulfoxide (DMSO) (Merck Chemicals (Pty) Ltd.), and serially diluted in broth (enriched for A. israelii and S. mutans) for the bacteria and sterile water for C. albicans; in the 96-well plate adding $48 \mathrm{~h}$ old microorganisms grown at $37^{\circ} \mathrm{C}$. The final concentration of extracts ranged from 0.10 to $12.5 \mathrm{mg} / \mathrm{ml}$ and the positive control, 5\% chlorhexidine gluconate (CHX) (Dental Warehouse, Sandton, South Africa), ranged from $3.8 \times 10^{-4}$ to $12.5 \mathrm{mg} / \mathrm{ml}$ for each microorganism tested. Amphotericin B (Davis Diagnostics, Gauteng) an established antifungal drug, ranging from $0.2 \mathrm{mg} / \mathrm{ml}$ to $1.5 \times 10^{-3} \mathrm{mg} / \mathrm{ml}$, was included for the Candida assays. The highest concentration of the solvent DMSO (5\%) was found to be non-toxic to the microorganisms tested. The plates inoculated with bacteria were incubated at $37^{\circ} \mathrm{C}$, under anaerobic conditions and the plates inoculated with $C$. albicans under aerobic conditions for $24 \mathrm{~h}$. 
To indicate bacterial growth, $20 \mu \mathrm{l}(0.2 \mathrm{mg} / \mathrm{ml})$ of INT, or PrestoBlue was added to micro-plate wells and incubated at $37^{\circ} \mathrm{C}$, under anaerobic conditions, for 20-60 min until a color change occurred. The MIC was defined as the lowest concentration that inhibited the color change of INT or PrestoBlue. The MBC was determined by adding $50 \mu \mathrm{l}$ of the suspensions from the wells, which did not show any growth after incubation during MIC assays, to $150 \mu \mathrm{l}$ of fresh broth. These suspensions were re-incubated at $37^{\circ} \mathrm{C}$ for $24 \mathrm{~h}$. The $\mathrm{MBC}$ was determined as the lowest concentration of extract which inhibited $100 \%$ growth of microorganisms (Cohen et al., 1998; Lall et al., 2013). All test samples, as well as the controls, were done in triplicate on the 96-well microtiter plates in three independent experiments.

\section{Determination of Cytotoxicity}

Human monocyte (U937) cells (ATCC: CRL 1593), Kidney epithelial cells of the African Green Monkey (Vero) and Human laryngeal epidermoid carcinoma (HEp-2) cells were used for testing the samples for cytotoxicity (Sigma-Aldrich, 2003). The cells were maintained in RPMI (Roswell Park Memorial Institute) medium supplemented with $10 \%$ fetal bovine serum (FBS) and $1 \%$ antibiotics ( $100 \mathrm{U} / \mathrm{ml}$ penicillin, $100 \mu \mathrm{g} / \mathrm{ml}$ streptomycin) and $250 \mu \mathrm{g} / \mathrm{ml}$ fungizone [supplied by Highveld Biological (Pty) Ltd., Johannesburg, South Africa]. The cells were grown at $37^{\circ} \mathrm{C}$ in a humidified incubator set at $5 \% \mathrm{CO}_{2}$. Cells were sub-cultured by centrifuging at $980 \mathrm{rpm}$ for $5 \mathrm{~min}$ and resuspending in fresh medium. The method described by Lall et al. (2013), was used to perform the assay. One hundred microliters of U937 cells $\left(1 \times 10^{5}\right.$ cells $\left./ \mathrm{ml}\right)$ were added to 96 well microtiter-plates and incubated for $24 \mathrm{~h}$ to allow the cells to differentiate and adhere as macrophages to the bottom of the plate. Stock solutions of the ethanol extract of $H$. natalensis were prepared in DMSO [Merck Chemicals (Pty) Ltd.]. The stock solutions were serially diluted in supplemented RPMI medium. The final concentration of $H$. natalensis ranged from 3.125 to $400 \mu \mathrm{g} / \mathrm{ml}$. The highest concentration of DMSO (2\%) was found to be non-toxic to the cells. The dilution series of the samples were added to the microtiter-plate and incubated for a further $72 \mathrm{~h}$. Thereafter $20 \mu \mathrm{l}$ PrestoBlue (Invitrogen Corporation, San Diego, CA, United States) was added to the plates of U937 cells away from direct light and the cells were incubated for 2-3 h. The Vero and HEp-2 cells cytotoxicity was measured by the XTT (Sodium 3'[1-(phenyl amino-carbonyl)-3,4-tetrazolim]-bis-[4 methoxy-6nitro] benzene sulfonic acid hydrate) method using the cell proliferation kit II (Roche Diagnostics $\mathrm{GmbH}$ ). The positive drug control Actinomycin D (Sigma-Aldrich, South Africa), at a final concentration range of $3.9 \times 10^{-4}-0.78 \mu \mathrm{g} / \mathrm{ml}$, was included in the assay. After incubation, the absorbance of the color complex was spectrophotometrically quantified using an enzyme-linked immunosorbent assay (ELISA) plate reader (BIO-TEK Power-Wave XS, Weltevreden Park, South Africa), which measured the optical density at $570 \mathrm{~nm}$ with a reference wavelength of $600 \mathrm{~nm}$ for the U937 cells and at $490 \mathrm{~nm}$ with a reference wavelength of $690 \mathrm{~nm}$ for the Vero and HEp-2 cells. The assays were carried out in triplicate.
The $\mathrm{IC}_{50}$ values were determined using GraphPad Prism version 4.03 .

\section{Acute and Sub-acute Toxicity in a Mouse Model}

The acute and sub-acute toxicity of the dried 96\% ethanolic extract of $H$. natalensis in mice was conducted by pathologists in the Faculty of Veterinary Science, University of Pretoria in Pretoria. The Animal Ethics Committee approved the investigation conducted on 64 mice by Professor V. Naidoo; (project number V065-14). A 2-week toxicity study with a once a day oral gavage dosing of $0 \mathrm{mg} / \mathrm{kg}, 50 \mathrm{mg} / \mathrm{kg}, 100 \mathrm{mg} / \mathrm{kg}$, and $200 \mathrm{mg} / \mathrm{kg}$, according to the OECD guideline 408 (repeated dose 90-day oral toxicity study in rodents) was conducted. Forty inbred CD1 mice, the recommended species for routine toxicity testing, were divided into four groups of equal sexes. Parameters investigated include: animal weights, feed intake, clinical signs of toxicity, gross necropsy, full histopathology, full hematology and selected clinical pathology.

\section{Reduction of Pro-inflammatory Response \\ Preparation of Heat-Killed Microorganisms}

When bacteria cause an infection, pro-inflammatory cytokines are released from cells and may cause tissue destruction through excessive inflammatory responses. IL- 8 is a chemokine, which is defined as a family of low-molecular weight pro-inflammatory cytokines that stimulate the recruitment of leukocytes. As A. israelii does not appear to stimulate significant production of IL-8; P. intermedia and C. albicans were selected for proinflammatory evaluation of ethanol extracts of $H$. natalensis. These microorganisms were cultured in their respective broths for $72 \mathrm{~h}$ at $37^{\circ} \mathrm{C}$ under anaerobic ( $P$. intermedia) and aerobic conditions (C. albicans). The log-phase microbial culture was harvested, washed three times with phosphate buffer saline (PBS) and incubated at $80^{\circ} \mathrm{C}$ for $20 \mathrm{~min}$ to kill the microorganism. The heat-killed microorganisms were stored at $4^{\circ} \mathrm{C}$ until use (Jiang et al., 1996; Tsai et al., 2010).

To determine whether the plant extract reduced the proinflammatory response of $P$. intermedia or $C$. albicans to the U937 cells, time-dependent studies were conducted. Firstly, $H$. natalensis extract, at $50 \%$ inhibitory concentration $\left(\mathrm{IC}_{50}\right)$ of $35.56 \mu \mathrm{g} / \mathrm{ml}$ and sub-cytokine value of $17.78 \mu \mathrm{g} / \mathrm{ml}$ (half the inhibitory concentration), was added separately to the prepared macrophages and $1 \mathrm{~h}$ later $P$. intermedia was added (Treatment 1). Secondly, the plant extract and $P$. intermedia were added to the macrophages together (Treatment 2) and lastly, $P$. intermedia was added to the macrophages with the plant extract being added $1 \mathrm{~h}$ later (Treatment 3 ). This process was repeated for the synergistic combinations for $P$. intermedia and C. albicans.

U937 cells were seeded at $1 \times 10^{6}$ cells $/ \mathrm{ml}$ in 24 -well plates with serum free medium, and were stimulated with LPS or heat killed P. intermedia or C. albicans (wet weight $100 \mu \mathrm{g} / \mathrm{ml}$ ) alone or in combination with the ethanolic extract of $H$. natalensis or the specified synergistic combination for each microorganism 
for $24 \mathrm{~h}$ incubation. Cell-free supernatants were collected and the concentration of IL-8 was analyzed with the enzyme-linked immunosorbent assay (ELISA) kit (Pharmigen, OptEIA Human IL-8 Set, catalog no. 555244) obtained from BD Bioscience (Tsai et al., 2010).

\section{Acid Analysis}

The L-Lactic test (Roche, R-Biopharm, Enzymatic BioAnalysis, catalog no. 10139084035) and Acetic acid test (Roche, R-Biopharm, Enzymatic BioAnalysis, catalog no. 101480261035) were conducted as described in the kits. Analysis of lactic and acetic acid from $S$. mutans and $L$. paracasei were carried out for the samples after $24 \mathrm{~h}$ incubation with the $H$. natalensis plant extract. The samples for lactic acid were collected at MIC and sub-minimum inhibitory concentrations (sub-MIC) which are half the MIC values; except for acetic acid which is not strongly produced, therefore only MIC samples were collected. As described in the kit manuals, the samples for lactic acid had to be adjusted to a pH between 8 and 10, and for acetic acid between, 8 and 9. Trial runs of each kit showed that the samples had to be suitably diluted to remain within the accuracy range of the enzymatic catalysis. Therefore, for both lactic and acetic acid, 1 in 10 dilutions were made from the samples; these were then adjusted to their correct $\mathrm{pH}$. Undiluted samples were also monitored for $\mathrm{pH}$ to determine whether the extract of H. natalensis and the synergistic combination for S. mutans as described in Henley-Smith et al. (2014), could increase the $\mathrm{pH}$ even in the presence of acid producing bacteria.

\section{Purification of Active Compounds}

The dried ethanolic extract of $H$. natalensis $(60 \mathrm{~g})$ was subjected to fractionation on a silica column $(10 \mathrm{~cm} \times 70 \mathrm{~cm})$ using a gradient of hexane:ethyl acetate of increasing polarity $(0 \%$ to $100 \%$ ethyl acetate) as eluent. Twenty-nine fractions were collected and those with similar thin layer chromatography (TLC) profiles were combined together. TLC plates were developed using hexane:ethyl acetate (7:3); hexane:ethyl acetate (8:2); dichloromethane:methanol (99.5:0.5) and dichloromethane:methanol (99:1) as eluent. Acidic vanillin ( $0.34 \%$ vanillin in $3.5 \%$ sulfuric acid in methanol) was used for detection. Thirteen major fractions (1B to 13B) were obtained and tested for antibacterial activity against $A$. israelii.

Based on the antibacterial results and preliminary TLC plates; Fractions 7B (2 g), 9B ( $3 \mathrm{~g}), 11 \mathrm{~B}(0.8 \mathrm{mg})$ and 12B $\left(\begin{array}{ll}1 & \mathrm{~g}\end{array}\right)$ were chromatographed separately using Sephadex columns (Sigma-Aldrich, South Africa). Fraction 7B was chromatographed using dichloromethane:methane (99.5:0.5). Sixty-four subfractions were collected, spotted on TLC plates and developed in dichloromethane:methane (99:1). Pure compound 1 (aurentiacin A; $87 \mathrm{mg}, 0.150 \%$ ) (Supplementary Figure 1) was obtained. Fraction 9B was chromatographed using $96 \%$ ethanol. Ninety-one sub-fractions were collected, spotted on TLC plates and developed in dichloromethane:methane (99.5:0.5). Pure compounds 2 (cardamomin; $2 \mathrm{mg}, 0,003 \%$ ) (Supplementary Figure 2) and 3 (5-hydroxy-7-methoxy-6methylflavanone, $22 \mathrm{mg}, 0,037 \%$ ) (Supplementary Figure 3) were obtained. Fraction $11 \mathrm{~B}$ was chromatographed using dichloromethane:methane (99:1). Fifty-five sub-fractions were collected, spotted on TLC plates and developed in dichloromethane:methane (99:1). Pure compound 4 (quercetin, $75 \mathrm{mg}, 0.130 \%$ ) (Supplementary Figure 4) was obtained. Fraction $12 \mathrm{~B}$ was chromatographed using dichloromethane:methane (99:1). Seventy-one sub-fractions were collected, spotted on TLC plates and developed in dichloromethane:methane (99:1). Pure compound 5 (3,5,7-trihydroxyflavan, $7 \mathrm{mg}, 0.012 \%)$ (Supplementary Figure 5) was obtained. Figure 1 shows the compounds identified. The identified compounds were then tested for antimicrobial activity.

\section{RESULTS AND DISCUSSION}

The ethanol extract of $H$. natalensis exhibited the best MIC value against $A$. israelii at $0.88 \mathrm{mg} / \mathrm{ml}$ (Table 1). Folk medicine from Brazil, used to treat oral diseases, was evaluated against P. intermedia and S. mutans by Alviano et al. (2008). Their study utilized Cocos nucifera, known to contain catechin and epicatechin; the inner bark of Ziziphus joazeiro; leaves of Caesalpinia pyramidalis and a 50\% ethanolic extract from Aristolochia cymbifera. Our investigation results for S. mutans $(2.6 \mathrm{mg} / \mathrm{ml})$ and lactobacilli $(9.38 \mathrm{mg} / \mathrm{ml})$ correspond with the results attained in the investigation by Alviano et al. (2008). However, the MIC for $P$. intermedia was observed to be higher $(12.5 \mathrm{mg} / \mathrm{ml})$ as compared to the MIC of the folk medicine from Brazil. The bacterial suspension used by Alviano et al. (2008) was standardized to a $0.5 \mathrm{McF}$ arland Standard as compared to the one used in the present study (1.0 McFarland Standard) which is almost double the bacterial suspension.

Several other medicinal plants have been investigated for activities against oral pathogens. The aqueous and methanol extract of the bark of Piptadeniastrum africanum, traditionally used for abdominal pain in Cameroon, was tested for inhibitory activity against $S$. mutans (ATCC 25175). Twofold serial broth macro-dilutions were used to determine the MIC with an average inoculum of $10^{7} \mathrm{CFU} / \mathrm{ml}$. An MIC of $1 \mathrm{mg} / \mathrm{ml}$ and $0.7 \mathrm{mg} / \mathrm{ml}$ was obtained for the aqueous and methanol extracts, respectively (Brusotti et al., 2013). Curcuma longa (turmeric) has been used in India to maintain oral hygiene. A methanol extract of $C$. longa was tested against $S$. mutans (UA159). The MIC was obtained at $1 \mathrm{mg} / \mathrm{ml}$ at a $1-1.5 \times 10^{6} \mathrm{CFU} / \mathrm{ml}$ (Pandit et al., 2011). The MIC values of the methanol extracts of $P$. africanum and C. longa are lower when compared to the activity of the ethanol extract of $H$. natalensis $(2.60 \mathrm{mg} / \mathrm{ml})$ against $S$. mutans. However, the bacterial suspension must be taken into consideration as a McFarland Standard 1.0 had a bacterial suspension density of $3.0 \times 10^{8} \mathrm{CFU} / \mathrm{ml}$ for S. mutans in the present investigation.

For the anti-yeast activity of $H$. natalensis, the extract was found to be relatively active with an MIC of $8.33 \mathrm{mg} / \mathrm{ml}$ obtained against a yeast suspension of $4 \times 10^{7}$ cells $/ \mathrm{ml}$, as compared to a study by Motsei et al. (2003), where no anti-candidal activity was obtained for their plants tested. As H. natalensis is not used traditionally for candidal infections, it compares well with plants cogitated to anti-candidal properties. An acetone extract of Dodonaea viscosa, another plant used in transitional 
<smiles>COc1cc(O)cc(O)c1C(=O)/C=C/c1ccccc1</smiles>

Cardamomin<smiles>COc1c(C)c(O)cc(O)c1C(=O)/C=C/c1ccccc1</smiles>

Aurentiacin A<smiles>Oc1cc(O)c2c(c1)OC(c1ccccc1)C(O)C2</smiles>

3,5,7-Trihydroxyflavan<smiles>O=c1c(O)c(-c2ccc(O)c(O)c2)oc2cc(O)cc(O)c12</smiles>

Quercetin<smiles>Cc1c(O)cc2c(c1O)C(=O)C[C@@H](c1ccccc1)O2</smiles>

5-Hydroxy-7-methoxy-6-methylflavanone

FIGURE 1 | Compounds identified from the fractions.

oral care, was tested for antifungal activity against C. albicans (ATCC 90028) inocula with $10^{6}-10^{7} \mathrm{cells} / \mathrm{ml}$. The MIC ranged from 6.25 to $25 \mathrm{mg} / \mathrm{ml}$ and correlated with our findings for H. natalensis (Patel and Coogan, 2008).

Bioassay guided isolation revealed the presence of five compounds in the extract of $H$. natalensis. These were, cardamomin, aurentiacin A, 5-hydroxy-7-methoxy6-methylflavanone, 3,5,7-trihydroxyflavan and quercetin (Figure 1). The MICs and MBCs of the isolated compounds against $A$. israelii are shown in Table 2. These revealed good inhibitor strength (below $1.5 \mathrm{mg} / \mathrm{ml}$ ) despite the lack of congruency on measuring strength as per the classification used by Nkomo et al. (2014). The crude extract exhibited an MIC value of $1.56 \mathrm{mg} / \mathrm{ml}$ and aurentiacin A showed the best activity at $0.0625 \mathrm{mg} / \mathrm{ml}$ against $A$. israelii.

The leaves of $H$. natalensis were examined for their phytochemical potential. A dichloromethane extract was eluted through silica gel from which a yellowish crystalline compound was obtained. It was determined to be a chalcone isomer of aurentiacin A and triangularin previously isolated from Myrica serrate and Pityrogramma triangularis. Spectroscopic data established the compound to be (E)-1-(2,4'-dihyroxy, 5'-methoxy, 3'-methylphenyl)-3-phenylprop-2-en-1-one (Adesanwo et al., 2009). Preliminary results from a study showed that (2E)-2-[(2E)-1-hydroxy-3-phenylprop-2en-1-ylidene]-5-methoxy-6,6-dimethylcyclohex-4-ene-1,3-dione, commonly known as ceroptin was also present in the leaf extract of $H$. natalensis (Shode et al., 2005).

The twigs and roots of $H$. natalensis were also investigated for phytochemicals. $\mathrm{A} \mathrm{CH}_{2} \mathrm{Cl}_{2}$ extract of the twigs yielded 2',4'-dihydroxy-6'-methoxy-3',5'-dimethylchalcone; 3,'4,5'-tri-O- methyl-3,4-methylenedioxyellagic acid and lupane derivatives betulinic acid. Hexane extracts of the twigs yielded lupenone and

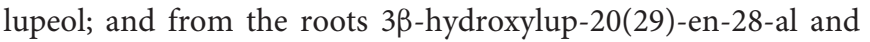
sitost-4-en-3-one (Mohammed et al., 2009).

As the use of any plant derived medicine invariably requires to be safe and not harmful to the body in any form, cytotoxicity analysis of extracts is imperative. Cytotoxicity tests revealed a general trend with the extract of $H$. natalensis, indicating a decrease in viability of U937 cells as the concentration of the samples tested increased. Actinomycin D was used as a viability control and demonstrated the marked decrease in viability on U937 cells tested in a dose-dependent manner. The cytotoxicity of the extract was determined as a percentage of the positive control, which were cells grown in medium only. The extract of $H$. natalensis showed an $\mathrm{IC}_{50}$ of $35.56 \pm 0.16 \mu \mathrm{g} / \mathrm{ml}$ $147 \pm 0.150 \mu \mathrm{g} / \mathrm{ml}$ and $33.66 \pm 0.04 \mu \mathrm{g} / \mathrm{ml}$ on macrophage U937 cells, Vero and HEp-2 cells, respectively. The positive control, Actinomycin D, showed IC 50 values of $1.6 \times 10^{-3} \pm 2.8 \times 10^{-4}$ $\mu \mathrm{g} / \mathrm{ml} 8.5 \times 10^{-3} \pm 9.95 \times 10 \mu \mathrm{g} / \mathrm{ml}$ and $0.06 \pm 2.44 \mu \mathrm{g} / \mathrm{ml}$ on macrophage U937 cells, Vero and HEp-2 cells, respectively. Therefore, on Vero cells, the extract of $H$. natalensis might be potentially harmful but on HEp-2 and U937 cells H. natalensis could be potentially toxic.

From the results of the animal trials, based on the absence of significant clinical or pathological effects being seen in the sub-acute study, it could be concluded that $H$. natalensis is not overtly toxic at the evaluated doses. While numerous changes were seen in clinical pathology, none of the changes showed a dose response relationship, and in most cases the effect was limited to the low dose group compared to the control. Changes were seen in the lymphocyte counts for the females. This change 


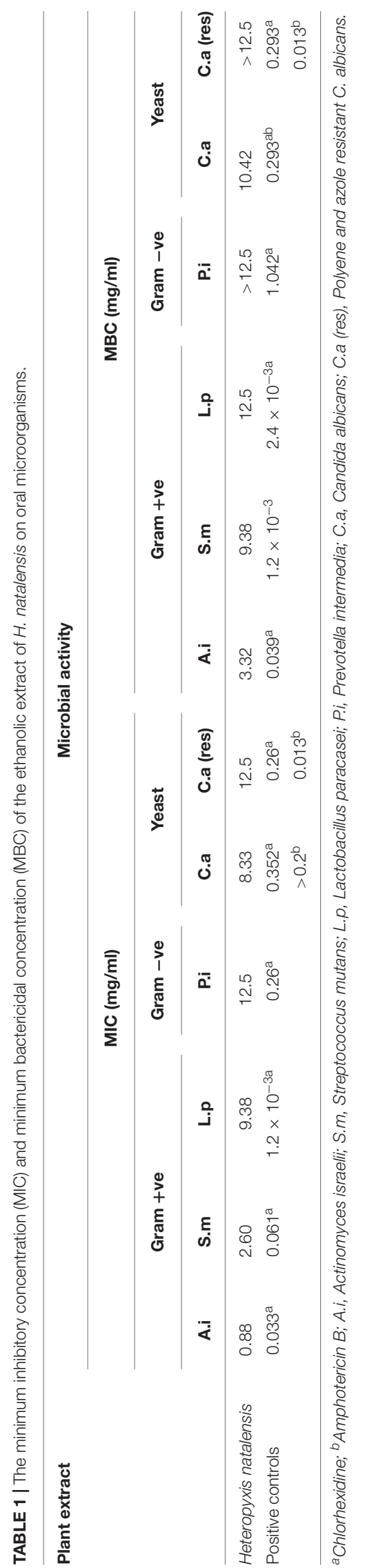

TABLE 2 | The minimum inhibitory concentration (MIC) and minimum bactericidal concentration (MBC) of the major fractions and isolated compounds from H. natalensis against Actinomyces israelii.

\begin{tabular}{lcc}
\hline Isolated compounds & MIC $(\mathbf{m g} / \mathbf{m l})$ & MBC $(\mathbf{m g} / \mathbf{m l})$ \\
\hline Heteropyxis natalensis & 1.5625 & 1.5625 \\
5-Hydroxy-7-methoxy-6-methylflavanone (3) & - & - \\
Aurentiacin A (1) & 0.0625 & 0.0625 \\
Cardamomin (2) & $>1$ & $\mathrm{NA}^{\mathrm{a}}$ \\
3,5,7-Trihydroxyflavan (5) & $>1$ & $\mathrm{NA}$ \\
Quercetin (4) & 1 & 1 \\
Positive control & $0.024^{\mathrm{b}}$ & $0.024^{\mathrm{b}}$ \\
Fractions & & \\
1B & $>12.5$ & $\mathrm{NA}$ \\
2B & $>12.5$ & $\mathrm{NA}$ \\
3B & $>12.5$ & $\mathrm{NA}$ \\
4B & $>12.5$ & $\mathrm{NA}$ \\
5B & 9.375 & 9.38 \\
6B & 9.375 & 9.38 \\
7B & 0.83 & 1.61 \\
8B & 0.83 & 2.34 \\
9B & 1.56 & 2.34 \\
10B & 2.21 & 8.20 \\
11B & 4.25 & 12.5 \\
12B & 12.5 & $\mathrm{NA}$ \\
13B & 1.82 & 5.47 \\
Positive control & 0.048828 \\
\hline & 0.018311 &
\end{tabular}

aNA, not active; ${ }^{b}$ Chlorhexidine.

was considered to be of negligible biological significance as it was still within reported strain reference intervals. The only other indication of toxicity was a change in absolute and relative liver weights for the male animals. For this parameter, the middle dose group average weight was significantly lower than the controls $(p<0.5)$, while the high dose group tended toward significance $(p<0.10)$. When this change was considered in conjunction with the other parameters of hepatotoxicity such as clinical pathology and histopathology, no general indication of hepatotoxicity was evident. As a result of the smaller liver weights, the no-observed-effect level (NOEL) was set at $50 \mathrm{mg} / \mathrm{kg}$ for males while the absence of concurrent clinical chemistry or histopathological changes expected for liver damage will result in a no-observed-adverse-effect level (NOAEL) of $200 \mathrm{mg} / \mathrm{kg}$ for males. For the combined group and females, the NOEL was set at $200 \mathrm{mg} / \mathrm{kg}$. Other plants with similar antibacterial activities to $H$. natalensis have been tested for acute toxicities in mice. An aqueous extract of the husk fiber of Cocos nucifera, known to contain catechin and epicatechin, the inner bark of Ziziphus joazeiro, leaves of Caesalpinia pyramidalis and a 50\% ethanolic extract from Aristolochia cymbifera were evaluated after different doses $(1-5 \mathrm{~g} / \mathrm{kg})$ were administered orally to mice. The mice were observed after 14 days and no weight loss or lethal effects were noticed in the mice at the tested doses, and a lethal dose for $50 \%$ of the population $\left(\mathrm{LD}_{50}\right)$ corresponded to $2 \mathrm{~g} / \mathrm{kg}$ (Alviano et al., 2008).

The anti-inflammatory results for $H$. natalensis showed that higher concentrations of $H$. natalensis led to an increased 
suppression of the production of IL-8. All the treatments with $H$. natalensis at the $\mathrm{IC}_{50}$ concentration of $35.56 \mu \mathrm{g} / \mathrm{ml}$ suppressed the release of IL- 8 by the cells, at least sixfold. The best results were obtained with Treatment 2, where the plant extract was added at the same time as the heat-killed $P$. intermedia. Even though the cells released some IL-8, when $H$. natalensis was added at the $\mathrm{IC}_{50}$ concentration it produced a reduction of IL-8. These results are also significant when comparing to the negative control of $P$. intermedia (410.39 pg/ml) (Figure 2).

Unlike $P$. intermedia, C. albicans did not induce a significant amount of IL-8, only $1.67 \mathrm{pg} / \mathrm{ml}$. For Treatment $1, H$. natalensis at an $\mathrm{IC}_{50}$ concentration of $35.56 \mu \mathrm{g} / \mathrm{ml}$ obtained virtually the same as the sub- $\mathrm{IC}_{50}$ concentration at 0.52 and $0.53 \mathrm{pg} / \mathrm{ml}$,

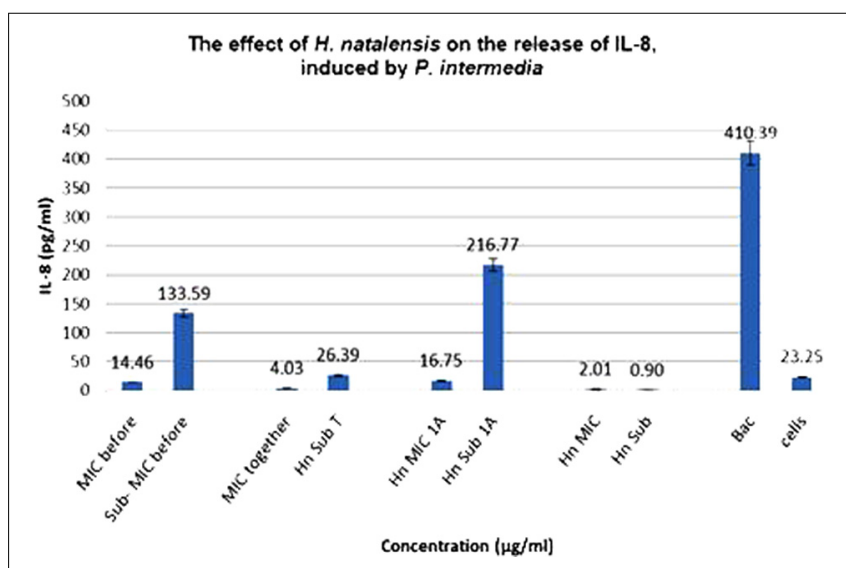

FIGURE 2 | The effect of Heteropyxis natalensis on the release of IL-8, taken in a time-dependent manner at an $\mathrm{IC}_{50}$ and Sub- $\mathrm{IC}_{50}$ concentration; as compared to the controls, Prevotella intermedia only (Bac,) and cells only. (Treatment 1 at MIC = MIC before; Treatment 1 at Sub-MIC = Sub-MIC before; Treatment 2 at MIC $=$ MIC together; Treatment 2 at Sub-MIC $=\mathrm{Hn}$ Sub T; Treatment 3 at MIC $=\mathrm{Hn}$ MIC 1 A; Treatment 3 at Sub-MIC $=\mathrm{Hn}$ Sub 1 $\mathrm{A} ; H$. natalensis at $\mathrm{MIC}=\mathrm{Hn} \mathrm{MIC} ; H$. natalensis at sub-MIC $=\mathrm{Hn}$ Sub).

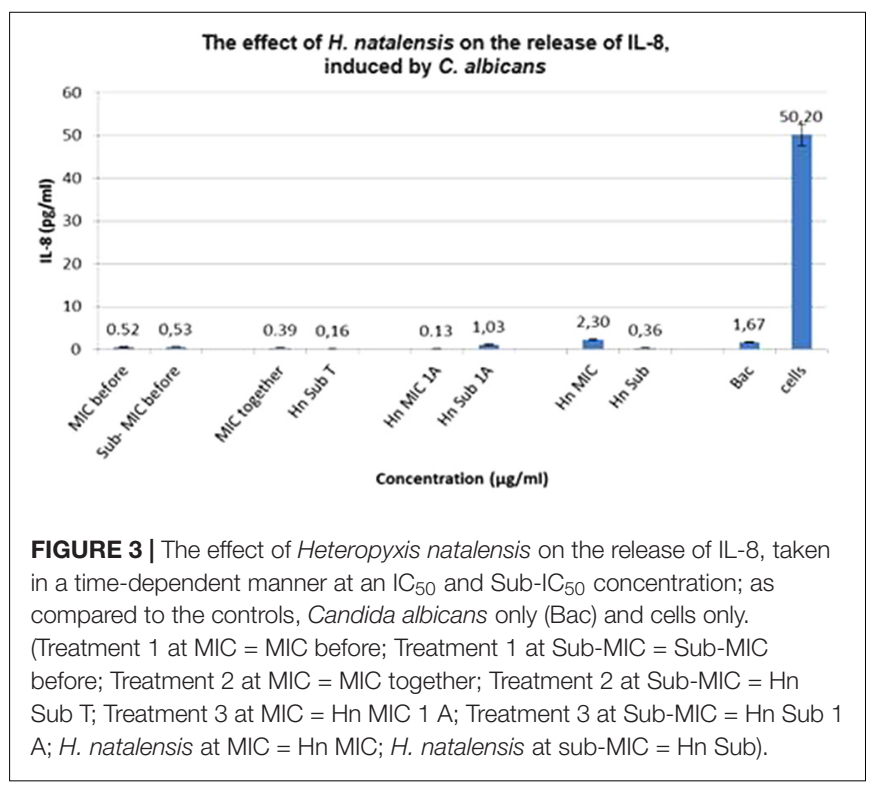

respectively. Treatment 3 , where $C$. albicans was added $1 \mathrm{~h}$ before the extract, resulted in the biggest difference with $\mathrm{IC}_{50}$ concentration suppressing IL-8 release to $0.13 \mathrm{pg} / \mathrm{ml}$ while the sub-IC $\mathrm{I}_{50}$ concentration could only suppress the IL-8 to 1.03 $\mathrm{pg} / \mathrm{ml}$ (Figure 3).

In response to bacterial stimuli and commensal bacteria, epithelial cells are thought to produce various pro-inflammatory cytokines. However, this stimulus by bacteria appears to be quite specific as some oral epithelial cells do not release an increase in the amount of pro-inflammatory cytokines such as IL-8. This may be in response to how epithelial cells interact with commensal bacteria to ensure that these cells do not produce pro-inflammatory cytokines which may lead to tissue destruction through an excessive inflammatory response. Another possibility is that the dose of the bacterial 'challenge' to the cells may also play a role (Jiang et al., 1998; Uehara et al., 2007).

In assessing acid production by $S$. mutans and $L$. paracasei. Results showed that acetic acid was not produced in large quantities by either S. mutans or L. paracasei (Table 3). However, $H$. natalensis at an MIC of $9.38 \mathrm{mg} / \mathrm{ml}$ reduced the amount of acetic acid produced by $L$. paracasei $(0.33 \mathrm{~g} / \mathrm{L})$ by almost half $(0.19 \mathrm{~g} / \mathrm{L})$. The acetic acid production by $S$. mutans $(0.26 \mathrm{~g} / \mathrm{L})$ was also reduced by the inhibitory concentration of $H$. natalensis (MIC of $2.6 \mathrm{mg} / \mathrm{ml}$ ). Lactobacillus paracasei, produced a large quantity of L-lactic acid (3.47 g/L) (Table 3).

Green tea has been found to halt the production of lactic acid by inhibiting bacterial lactate dehydrogenase which may explain the latter activity (Song and Seong, 2007). The decrease in $\mathrm{pH}$ was significantly inhibited in S. mutans and L. paracasei with the presence of $H$. natalensis extract for each bacterium. Once the $\mathrm{pH}$ level falls below 5.0 to 5.5 , enamel demineralization occurs (Loesche and Grossman, 2001). The H. natalensis extract at MIC and sub-MIC values appeared to prevent enamel demineralization with both bacterium.

TABLE 3 | Acetic acid and L-lactic acid production by Streptococcus mutans and Lactobacillus paracasei on exposure to ethanolic extract of $H$. natalensis.

\begin{tabular}{|c|c|c|c|c|}
\hline \multirow{2}{*}{$\begin{array}{l}\text { L-Lactic acid } \\
\text { production }\end{array}$} & \multicolumn{2}{|r|}{ S. mutans } & \multicolumn{2}{|r|}{ L. paracasei } \\
\hline & $\mathrm{pH}$ & $\begin{array}{c}\text { g acetic } \\
\mathrm{acid} / / \mathrm{l} \text { sample sol }\end{array}$ & $\mathrm{pH}$ & $\begin{array}{c}\text { g acetic } \\
\text { acid/l sample sol }\end{array}$ \\
\hline $\begin{array}{l}\text { H. natalensis - } \\
\text { MIC }\end{array}$ & 5.84 & 0.22 & 5.51 & 0.16 \\
\hline $\begin{array}{l}\text { H. natalensis - } \\
\text { Sub-MIC }\end{array}$ & 5.78 & 0.21 & 5.73 & 0.11 \\
\hline $\begin{array}{l}\text { Negative } \\
\text { control }\end{array}$ & 4.32 & 1.38 & 3.63 & 3.47 \\
\hline \multicolumn{5}{|l|}{$\begin{array}{l}\text { Acetic acid } \\
\text { production }\end{array}$} \\
\hline $\begin{array}{l}\text { H. natalensis - } \\
\text { MIC }\end{array}$ & 5.84 & 0.21 & 5.51 & 0.19 \\
\hline $\begin{array}{l}\text { Negative } \\
\text { control }\end{array}$ & 4.32 & 0.26 & 3.63 & 0.33 \\
\hline
\end{tabular}

MIC, minimum inhibitory concentration; Sub-MIC, half the minimum inhibitory concentration; negative control, bacteria only. 
Heteropyxis natalensis exhibited activity against the Grampositive microorganisms, A. israelii and $S$. mutans and reduced activity against the Gram-negative bacteria, $P$. intermedia. The acute and sub-acute toxicity of $H$. natalensis was conducted by pathologists at the Faculty of Veterinary Science, University of Pretoria and results indicated that the NOEL was set at $200 \mathrm{mg} / \mathrm{kg}$. It is possible that $H$. natalensis can prevent excessive tissue damage in periodontal diseases through its reduction of pro-inflammatory cytokine concentrations. $H$. natalensis exhibited the ability to reduce acid production by $S$. mutans and $L$. paracasei. Consequently, this increased the $\mathrm{pH}$, possibly reducing the demineralization of enamel which should help prevent the formation of dental caries.

\section{CONCLUSION}

The work reports for the first time $H$. natalensis activity against A. israelii, $L$. paracasei, as well as its in vivo acute and sub-acute toxicity. Five isolated compounds were identified for the first time from the ethanolic extract of $H$. natalensis leaves and twigs. The compounds were identified as aurentiacin A (1), cardamomin (2), 5-hydroxy-7-methoxy-6-methylflavanone (3), quercetin (4) and 3,5,7-trihydroxyflavan (5). The extract of $\mathrm{H}$. natalensis was able to reduce the acid produced by the bacteria $S$. mutans and $L$. paracasei, which duly increased the $\mathrm{pH}$. H. natalensis has the potential to reduce the growth and metabolic effects of cavity

\section{REFERENCES}

Adesanwo, J. K., Shode, F. O., Aiyelaagbe, O., Oyede, R. T., and Baijnath, H. (2009). Isolation and characterization of a new chalcone from the leaves of Heteropyxis natalensis. Int. J. Med. Med. Sci. 1, 28-32.

Alviano, W. S., Alviano, D. S., Diniz, C. G., Antoniolli, A. R., Alviano, C. S., Farias, L. M., et al. (2008). In vitro antioxidant potential of medicinal plant extracts and their activities against oral bacteria based on Brazilian folk medicine. Arch. Oral Biol. 53, 545-552. doi: 10.1016/j.archoralbio.2007. 12.001

Brusotti, G., Tosi, S., Tava, A., Picco, A. M., Grisoli, P., Cesari, I., et al. (2013). Antimicrobial and phytochemical properties of stem bark extracts from Piptadeniastrum africanum (Hook f.) Brenan. Ind. Crops Prod. 43, 612-616. doi: 10.1016/j.indcrop.2012.07.068

Cohen, M. A., Husband, M. D., Yoder, S. L., Gage, J. W., and Roland, G. E. (1998). Bacterial eradication by clinafloxacin, CI-990, and ciprofloxacin employing MBC test, in-vitro time kill and in-vivo time-kill studies. J. Antimicrob. Chemother. 41, 605-614. doi: 10.1093/jac/41.6.605

Eloff, J. N. (1998). A sensitive and quick microplate method to determine the minimal inhibitory concentration of plant extract for bacteria. Planta Med. 64, 711-713. doi: 10.1055/s-2006-957563

Henley-Smith, C. J., Botha, F. S., Steffens, F. E., and Lall, N. (2014). Predicting the influence of multiple components on microbial inhibition using a logistic response model - a novel approach. BMC Complement. Altern. Med. 14:190. doi: 10.1186/1472-6882-14-190

Jiang, Y., Russell, T. R., Graves, D. T., Cheng, H., Nong, S.-H., and Levitz, S. M. (1996). Monocyte chemoattractant protein 1 and interleukin-8 production in mononuclear cells stimulated by oral microorganisms. Infect. Immun. 64, 4450-4455.

Jiang, Y., Russell, T. R., Schilder, H., and Graves, D. T. (1998). Endodontic pathogens stimulate monocyte chemoattractant protein-1 and interleukin-8 in mononuclear cells. J. Endod. 24, 86-90. doi: 10.1016/S0099-2399(98) 80083-6 causing bacteria, while only moderately affecting commensal bacteria. The results indicated the possible use of $H$. natalensis to prevent excessive tissue damage in periodontal diseases through its reduction of pro-inflammation.

\section{AUTHOR CONTRIBUTIONS}

CH-S, NL, DM, FB, AH, and MN planned the experiments and/or wrote the manuscript. $\mathrm{CH}-\mathrm{S}$ performed the experiments. $\mathrm{CH}-\mathrm{S}$, $\mathrm{FB}$, and NL carried out the data analysis. NL and FB supervised all work. All authors critically revised and approved the final version of the manuscript.

\section{FUNDING}

These studies were supported by the National Research Foundation (Grant 90355), NRF innovation doctoral scholarship as well as the Gen Foundation Grant (from National Trust, United Kingdom).

\section{SUPPLEMENTARY MATERIAL}

The Supplementary Material for this article can be found online at: https://www.frontiersin.org/articles/10.3389/fphar. 2018.00291/full\#supplementary-material

Klančnik, A., Piskernik, S., Jeršek, B., and Možina, S. S. (2010). Evaluation of diffusion and dilution methods to determine the antibacterial activity of plant extracts. J. Microbiol. Methods 81, 121-126. doi: 10.1016/j.mimet.2010. 02.004

Lall, N., Henley-Smith, C. J., De Canha, M. N., Oosthuizen, C. B., and Berrington, D. (2013). Viability reagent, PrestoBlue, in comparison with other available reagents, utilized in cytotoxicity and antimicrobial assays. Int. J. Microbiol. 2013:420601. doi: 10.1155/2013/420601

Loesche, W. J., and Grossman, N. S. (2001). Periodontal diseases as specific, albeit chronic, infection: diagnosis and treatment. Clin. Microbiol. Rev. 14, 727-752. doi: 10.1128/CMR.14.4.727-752.2001

McFarland, J. (1907). The nephelometer: an instrument for estimating the number of bacteria in suspensions for calculating the opsonic index and for vaccines. J. Am. Med. Assoc. 49, 1176-1178. doi: 10.1001/jama.1907.25320140022001f

Mohammed, A. M. A., Coombes, P. H., Crouch, N. R., and Mulholland, D. C. (2009). Non-volatile isolates of two Heteropyxis species: a first chemotaxonomic assessment of subfamily Psiloxyloideae (Myrtaceae). Biochem. Syst. Ecol. 37, 241-243. doi: 10.1016/j.bse.2009.03.006

Motsei, M. L., Lindsey, K. L., van Staden, J., and Jäger, A. K. (2003). Screening of traditionally used South African plants for antifungal activity against Candida albicans. J. Ethnopharmacol. 86, 235-241. doi: 10.1016/S0378-8741(03) 00082-5

Nkomo, M. M., Katerere, D. D., Vismer, H. H., Cruz, T. T., Balayssac, S. S., Malet-Martino, M. M., et al. (2014). Fusarium inhibition by wild populations of the medicinal plant Salvia africana-lutea L. linked to metabolomic profiling. BMC Complement. Altern. Med. 14:99. doi: 10.1186/1472-6882-14-99

Pandit, S., Kim, H., Kim, J., and Jeon, J. (2011). Separation of an effective fraction from turmeric against Streptococcus mutans biofilms by the comparison of curcuminoid content and anti-acidogenic activity. Food Chem. 126, 1565-1570. doi: 10.1016/j.foodchem.2010.12.005

Patel, M., and Coogan, M. M. (2008). Antifungal activity of the plant Dodonaea viscosa var. angustifolia on Candida albicans from HIV-infected patients. J. Ethnopharmacol. 118, 173-176. doi: 10.1016/j.jep.2008.03.009 
Shode, F. O., Oyede, R. T., Adesanwo, J. K., and Baijnath, H. (2005). "Extractives from Heteropyxis natalensis," in Proceedings of the 11th NAPRECA Symposium Book, Antananarivo, 187-192.

Sigma-Aldrich (2003). Sigma-Aldrich Cell Culture Manual. St. Louis, MO: SigmaAldrich.

Song, J. M., and Seong, B. L. (2007). Tea catechins as a potential alternative antiinfectious agent. Expert Rev. Anti Infect. 5, 497-506. doi: 10.1586/14787210.5. 3.497

Tsai, T.-H., Tsai, T.-H., Wu, W.-H., Tseng, J. T.-P., and Tsai, P.-J. (2010). In vitro antimicrobial and anti-inflammatory effects of herbs against Propionibacterium acnes. Food Chem. 119, 964-968. doi: 10.1016/j.foodchem.2009.07.062

Uehara, A., Fujimoto, Y., Fukase, K., and Takada, H. (2007). Various human epithelial cells express functional Toll-like receptors, NOD1 and NOD2 to produce anti-microbial peptides, but not proinflammatory cytokines. Mol. Immunol. 44, 3100-3111. doi: 10.1016/j.molimm.2007.02.007

Van Wyk, B., and Gericke, N. (eds) (2000). "General medicines, chapter 7. Dental care, chapter 12. Perfumes and repellents, chapter 13," in People's Plants, (Pretoria: Briza Publications), 119-228.

Van Wyk, B., and Van Wyk, P. (1997). Field Guide to Trees of Southern Africa. Cape Town: Struik Publishers, 198-500.
Van Wyk, B.-E. (2011). The potential of South African plants in the development of new medicinal products. S. Afr. J. Bot. 77, 812-829. doi: 10.1016/j.sajb.2011. 08.011

Yu, H.-H., Lee, J.-S., Lee, K.-H., Kim, K.-Y., and You, Y.-O. (2007). Saussurea lappa inhibits the growth, acid production, adhesion, and water-insoluble glucan synthesis of Streptococcus mutans. J. Ethnopharmacol. 111, 413-417. doi: 10.1016/j.jep.2006. 12.008

Conflict of Interest Statement: The authors declare that the research was conducted in the absence of any commercial or financial relationships that could be construed as a potential conflict of interest.

Copyright (c) 2018 Henley-Smith, Botha, Hussein, Nkomo, Meyer and Lall. This is an open-access article distributed under the terms of the Creative Commons Attribution License (CC BY). The use, distribution or reproduction in other forums is permitted, provided the original author(s) and the copyright owner are credited and that the original publication in this journal is cited, in accordance with accepted academic practice. No use, distribution or reproduction is permitted which does not comply with these terms. 